\title{
The United Nations Juvenile Criminal Judicial Criteria: Implementation and Realization in China
}

\author{
Lei Xiaozheng \\ College of Criminal Law Science \\ Beijing Normal University \\ Beijing, China \\ leixiaozheng@163.com
}

\author{
Chen Qian \\ College of Criminal Law Science \\ Beijing Normal University \\ Beijing, China \\ chenqian20160401@163.com
}

\begin{abstract}
Through phased achievements in the theory of juvenile justice system and minors' criminal law legislation and its judicial system have been established by China, it still has to overcome difficulties and establish itself. This article applies the method of comparative study, and it aims to implement and realize the concept of maximizing children's benefits of United Nations criminal judicial criteria and the principle of special protection of litigation rights system. It is necessary to improve juvenile criminal law and juvenile criminal procedure. At the same time, it also needs to rely on the social governance innovation, risk assessment reinforcement, and social investigation, etc.
\end{abstract}

Keywords-Juvenile criminal justice; Children's benefits maximum; Litigation rights; Social governance

\section{INTRODUCTION}

Pursuant to the United Nations criminal judicial criteria, which aims to maximize children's benefits, the International Covenant on Civil and Political Rights, the Convention on the Rights of Children, the Rules of Bottom Standard of Juvenile Justice of the United Nations(also known as Beijing Rules), "the Rules of the United Nations to Prevent Juvenile Delinquency" (also known as "Riyadh Guidelines"), the Rules of Treatment of Bottom Standard of Prisoners, and the Rules of Protection for Liberty-deprived Youngest and so forth set for a series of rational principles for minors' criminal justice, requiring that special protection be conducted in forms of substantive law, procedural law and legal policy, etc, regarding specialty of minors. These rational principles are designed initially to make some of the lowest, benchmark, specification of consensus in terms of protecting the legal rights and interests of minors, under distinctive social atmosphere and legal systems, so as to lead the countries to establish operational principles and specific standards. Judging from the current legislative and judicial reforms in China, we can see many do meet the basic instruction and requirements by the principles of criminal justice of the United Nations, for example, the International Covenant on Civil and Political rights; but in effect they are still subject to various factors, and thus lag behind. It is a frontier problem to Implement and realize the United Nations juvenile criminal judicial criteria for China judicial reform.

\section{THE PRINCIPLE SYSTEM OF THE RULES OF BOTTOM STANDARD OF JUVENILE JUSTICE OF THE UNITED NATIONS}

Internationally, definitions are with great discrepancy of children, youth, adolescents and minors, etc. According to the definition of the Rules of Bottom Standard of Juvenile Justice of the United Nations, youth refers to children or youngsters whose illegal behavior, according to respective national legal system, can be dealt with in a way that differs from that with adults [1]. To avoid ambiguity, this article defines minor crimes and its criminal judicial procedure in the context of crimes under 18 . In the minors in the criminal justice, there should be no blind emphasis on punishment of crime. Thus, litigation rights special protection is the key of the juvenile criminal justice differs from adult criminal justice principle [2] Generally speaking among the criminal lawsuit, minors should enjoy some different litigation rights than adults, and the judicial organs shall have the duty to the litigation rights of minors to give special attention and protection. This paper defines that public rational basic principles, it is to point to reflect the inherent law of minors' criminal justice and qualities, and beyond the specific countries, differences between people, legal principles for the existence of rational and benchmark. It is the core and essence of minor criminal justice concept. In criminal judicial criteria of the United Nations, China signed but not yet approved, the International Covenant on Civil and Political Rights play an important role in the protection of human rights in minors criminal justice, and is even the wind and coordinate on how to carry out special protection, which shows particularly in the following aspects: special safeguard of the right to life, which forbids that death penalty be applied to people under the age of 18; special care when in custody, which calls for holding separately and giving corresponding treatment; trial in camera in order to protect their privacy; application should take into account the age and the need of social rehabilitation. In conjunction with other international treaties, based on the maximization of children's interests, the provisions of the United Nations juvenile criminal justice standard are mainly embodied in the following aspects: 


\section{A. Professional principles and the processing requirement, respectively}

The United Nations the minimum standard rules also for minors were in custody and the place of execution respectively made a more detailed rules. Article 13.4 hereof, for example, "pre-trial detention teenager should be separated from adult supervision, should be arrested in a separate of detained in adult prisons or separate parts". Article 26.3 hereof, "should be separate imprisoned youths and adults, they should be held in a prison or held in a separate part of the adult prison." The implementation of the separation principle requires special requirements to the investigators. Juvenile justice of the United Nations the minimum standard rules of article 2.3 hereof, efforts should be made to within the scope of jurisdiction in every country to formulate a set of specially applicable to juvenile laws, rules and regulations, and establish the authorized the implementation of institutions and organs of juvenile justice; Stipulated in article 22, for these personnel requires a minimum of law, sociology, psychology, criminology and behavioral science knowledge.

\section{B. Quickly simplified principle}

The juvenile justice of the United Nations the minimum standard rules stipulated in article 20.1: "Each case should be dealt with quickly from the start, should not have any unnecessary delay." The United Nations (UN) protection are deprived of their liberty by young rules also provisions of article 17: "In the case of had to take preventive detention, juvenile court and research should be given the priority, in the most efficient way to handle this case, to ensure that as much as possible to shorten the time of detention."

\section{Publicly, file storage and secrecy}

The juvenile justice of the United Nations the minimum standard rules stipulated in article 8.1, "should be respect in all phases of the juvenile delinquents shall enjoy the right to privacy and to avoid because of the inappropriate to promote or to name and cause harm to its"; "for juvenile criminals files should be strictly confidential and shall not make use of third party".

The juvenile justice of The United Nations the minimum standard rules stipulated in article 15 , "in the process of the whole proceedings, young shall have the right by a legal consultant on behalf of, or in providing compulsory legal aid country to apply for the legal aid", "parents or guardians shall have the right to participate in litigation, the competent authorities can ask them for the benefit of the youth to participate in litigation.

From countries to implement the litigation rights of the special protection principle system of experience, in addition to the criminal law, criminal procedure law specifically stipulated special chapter, its judicial resource allocation situation of a country, the condition of professional personnel, and the condition of social welfare support elements were given higher requirements. In other words, when these elements are more complete, and perfect, special protection of juvenile criminal judicial litigation rights can be in place actually. The controversy is, of course, on the basis of and the juvenile criminal procedure, relative to the adult criminal proceedings, it itself has some "inefficient" features: Many reflect special litigation rights program setting behavior and the lawsuit request judicial authorities and relevant government, social institutions, give full play to the initiative, put in more manpower and material resources and financial resources. Especially some not crime, not in custody, not to prosecute, non-confinement measure greatly promote the humanistic concern for the "juvenile justice", as well as illegal crime, will be the opposite of these measures, to prevent litigation case the degree of control in the social from all walks of life can endure, this is not without cost. In this sense, juvenile justice is the crown of the legal system, but also expensive crown.

\section{The Value Evaluation of the United Nations JUVENILE JUSTICE GUIDELINES}

In juvenile criminal justice system, the diversification benefits balance mainly embodied in the understanding and implementation of the concept of bidirectional protection. Juvenile justice as part of the criminal justice should not only pay attention to the security and safeguard social order, and through certain prohibited specifications to ensure that the country's own survival condition and the social protection function; At the same time, also need to consider the particularity of minors, pay attention to protect the interests of the minors, to combine the two, to protect the interests of the society and to protect the interests of the minors organic unity. For the precaution and protection of the minor crime from pure judicial prevention and protection extend to the social governance system. The juvenile justice of the United Nations the minimum standard rules in the third part "judge and deal with" in article 17.1 a for the benefits balance again once again: Take the reaction not only should be commensurate with the situation of the crime and severity, and shall be commensurate with young situation and the need and the need of society. Associated with it is that the United Nations guidelines on the power of attorney to empower the procuratorial organs in juvenile cases, should according to the legal position, social interest insist again to control on the prosecution discretion, according to the proportion principle such as flexible disposal. icle 19 , the prosecutor has to decide whether to juvenile prosecution discretion, dealing with the nature of the crime and the severity and the character and background to protect social and teens experience given special consideration. In making this decision, the prosecutor should be based on the special method of juvenile justice and program considered feasible way to Sue.

How to more fully grasp and implement two-way protection? In the juvenile criminal justice, comprehensive social survey requires judicial organs in handling criminal cases of minors in the process, as well as investigating the case facts of minors, and try to find out cause minor crime the subjective and objective factors of the formation, development, evolution and the minor's special character and so on details, especially the prosocial, social psychology and behavior [3]. Of course, some non-rigid juvenile judicial way even is not a crime, there are also many disputes. Vicious crime, for example, early onset phenomenon, especially those involving murder, rape, robbery, drug trafficking, judicial intervention too limit are thought to be associated with the value of the criminal justice 
goals may be serious conflict. In extreme crime, based on the interests balance, such as the victim, on the death penalty for minors is, the United States and Japan judiciary caused quite a stir, long time not calm. In principle the same dispute also exist in the judicial intervention in moderation. In juvenile correctional aspects involved sin, we also see that as a result of racial discrimination, religious conflict, between the rich and the poor increased, drug abuse and other factors, object outside many treatments still feel discriminated against, forgotten, and then to crime again. It is indisputable fact. In some illegal crime gang, some tried to walk into "succession" trajectory of minors become relatively fixed "people" problem, rectification is difficult. People begin to reflect on: Treatments of the minors to wade sin, fully believe in and depend on due process of law and the modern psychological science, reliable?

\section{THE DEVELOPMENT OF CHINA'S MINOR CRIMINAL JUSTICE IN SOCIAL GOVERNANCE}

In implementing the UN children's concept of benefit maximization in the criminal judicial criteria, according to the requirements of social justice, the illegal crime teenagers not only have corresponding rights (entitlements), shall also have the ability to use these rights (capacity) [4].

\section{A. Face to face with minor criminal justice for the risk of social governance}

From the perspective of social governance, we should note that some of the minor crime in China's new trends and problems. For example, minor crime of younger age, malignant, especially violent, increasingly prominent. In recent years, robbery, rape, statutory rape, murder and intentional injury serious crime of violence of juvenile criminal accounted for about $50 \%$ of all the criminals in some cities, including extreme cases of malignant [5]. In the network crime and drug-related, wade could case, minor crime problems are increasingly prominent.

Chinese government and judicial organs, public institutions and give them practical and effective help, especially the need to acquire related crime minors "substantial risk factor", "moral hazard factor" and "psychological risk factors", etc. So to speak, reduce the risk of involving crime minors, from the point of profound, is the core issue of social governance innovation.

\section{B. Perfect risk assessment and social investigation mechanism}

Compared with the United Nations criminal judicial criteria, the juvenile criminal judicial protection of human rights, China's weaknesses mainly reflected on the social support system. This can be seen in the social investigation system of adult criminal cases. In the field of juvenile criminal justice, social survey is a basic system in social phenomena, it is a lot of juvenile criminal justice system and litigation rights special protection principles can be carry out and implement the premise. Against crime, the reason for involving crime minors custody, upbringing, education, psychology, and so on and so forth of investigation and risk assessment, not only is the important reference case, also can assess its important basis, how to return to society. Assessment is helpful to predict the special crime and crime assess the risk of future violence, recognition and tracking high-risk crime, etc. Minors in the criminal justice in our country, can rely on the social management innovation, strengthen the risk assessment in the minors' criminal procedure as the assessment of detention, prosecution, sentencing, referral, community correction and other evidence materials: One is should insist on the combination of static and dynamic, objective and subjective support, punishment and guarantee phase equilibrium, the principle of combination of inner and outer, etc; two it is to plan as a whole use of psychological test conclusion and social investigation report, on the basis of high, medium and low level to distinguish the risk coefficient.

\section{Improve the practical ability of returning to society}

At present, in view of the minor crime, various circles in China come to some agreement with growing in China, such as a minor criminal justice can not pay attention to punishment, like adult criminal justice must be stressed on the special protection of minors and the mitigation processing, pay attention to the minors' psychology and behavior of the comprehensive social investigation, on the program should be given their age and need to help them. This has to do with the international covenant on civil and political rights such as the United Nations human rights protection in criminal judicial criteria requirements are consistent. The technology gap is, of course, the risk assessment in minor criminal cases in China, referral, main research experiences growing up in return to society, monitoring conditions, such as criminal records, the education situation static information and external information, history; The lack of psychological problems and cognitive status, antisocial personality, and behavior patterns such as internal information, dynamic information, information collection. More important, of course, is how to improve the efficacy of such information for mental and behavioral correction. Currently, there is a particular need to implement psychological counselling which is based on risk coefficient, the behavior modification plan which aims to help juvenile repair their relationship with the community, as well as the relationship with the victim. These seem to "cure" measures, which is beneficial to protect the rights of minors in criminal judicial proceedings the implementation of special protection principle, and keep the necessary balance and the interests of the social security.

\section{CONCLUSION}

The development of Chinese human rights action plan and juvenile justice has alluded to the shrinking of the gap, and we're even in the leading position in some fields. Many benign reform measures also provide pertinent experience for the development of the world's human rights protection of minors. There exists no substantial gap between our provisions and the United Nations' criminal judicial criteria, from the perspective of their external forms. However, from that of their judicial operation, Chinese human rights protection of juvenile criminal justice is still staggering in its competence. However, from that of their judicial operation, Chinese human rights protection of juvenile criminal justice is still staggering in its competence. Especially, in government purchase services, risk assessment, referrals, etc., there are still many institutional constraints. Chinese juvenile criminal justice for conflict in the 
value target of how to balance and adjustment, dispel, fixed some conflict with the United Nations rule of criminal justice and rational principles of ideas and practices, it is the most basic proposition.

\section{REFERENCES}

[1] Wang Junping, "United Nations Covenant on Civil and Political Rights", Beijing: Intellectual Property Right Press, 2013.pp.100-101.

[2] Yang Yuguan, "Human Right Law--International Covenant on Civil and Political Right", Beijing: Chinese People's Public Security University press, 2003, p.307.

[3] Chen Guangzhong, "Criminal Judicial Criterion of the United Nations and China Criminal Law", Beijing: Law Press, 1998, p.411.

[4] Stewart Asquith \& Malcolm Hill (eds.), Justice for Children, Dordrecht: Martinus Nijhoff Publishers, 1994, pp.144-156.

[5] Cao Xuecheng, "China's Minor Crime Trends Data Report", Beijing: Legal Daily Press, September 1, 2010. 